\title{
Co-existence of methane- and sulphur-based endosymbioses between bacteria and invertebrates at a site in the Skagerrak
}

\author{
R. Schmaljohann ${ }^{1}$, E. Faber ${ }^{2}$, M. J. Whiticar ${ }^{2}$, P. R. Dando ${ }^{3}$ \\ ${ }^{1}$ Institut für Meereskunde an der Universität Kiel, Düsternbrooker Weg 20, D-2300 Kiel, Federal Republic of Germany \\ ${ }^{2}$ Bundesanstalt für Geowissenschaiten und Rohstoffe, Stilleweg 2, D-3000 Hannover 51, Federal Republic of Germany \\ ${ }^{3}$ Marine Biological Association of the UK, Citadel Hill, Plymouth PL1 2PB, United Kingdom
}

\begin{abstract}
A small pogonophore from the Skagerrak, Siboglinum poseidoni, lives in symbiosis with methane-oxidizing bacteria. This was confirmed by the presence of 2 enzymes characteristic of bacterial C1-metabolism, methanol dehydrogenase and hexulosephosphate synthetase, in the bacteria-containing tissues. Specific activities were comparable to those found in free-living methane-oxidizing bacteria and in bacteria-containing tissues from other invertebrates with symbiotic methanotrophs. Stable carbon isotope ratios for tissues of pogonophores and other animals from the habitat were compared with those for organic matter in the sediment and for free and sorbed hydrocarbon gases. Free, biogenic methane $\left(0{ }^{13} \mathrm{C}=-80.3 \%\right.$ PDB $)$ was the carbon source for $S$. poseidoni $\left(0^{13} \mathrm{C}=-78.3 \%\right.$ in its bacteriacontaining posterior parts). Methane sorbed to the sediment is probably not accessible to the organism. Tissue of the bivalve mollusc Thyasira sarsi from the same habitat was less ${ }^{13} \mathrm{C}$-depleted $\left(0{ }^{13} \mathrm{C}=-37.4\right.$ to $-39.5 \%$, although more depleted than specimens found in sites with negligible methane. The value for the bivalve can be explained by available bicarbonate depletion and selection for ${ }^{12} \mathrm{C}$ by chemoautotrophic sulphur-oxidizing symbiotic bacteria in the gills. No methylotrophic enzymes were found in gill extracts. A heterotrophic polychaete apparently not influenced by symbiotic methanotrophs, Leanira sp., has a $\mathrm{d}^{13} \mathrm{C}$-value $(-20.0 \%$ ) comparable to phytoplankton or organic matter from the sediment $(-25 \%)$.
\end{abstract}

\section{INTRODUCTION}

The small pogonophore Siboglinum poseidoni, which occurs in the central Skagerrak, is known to harbour methylotrophic endosymbiotic bacteria (Schmaljohann \& Flügel 1987). This was confirmed by TEM-micrographs, culture experiments and ${ }^{14} \mathrm{CH}_{4}$ uptake data. This organism is ideal for studies on this type of symbiosis since it has only one type of endosymbiont and does not possess a digestive tract. Therefore results can be more easily interpreted than in species which have a mixed nutrition either by different types of symbionts, or by a functional digestive tract, as in some symbiotic bivalves.

Methane-oxidizing bacteria endosymbiotic in bivalves have been confirmed from 2 sites in the Gulf of Mexico. Cavanaugh et al. (1987) investigated such a symbiosis in the gills of a mytilid bivalve from the Florida escarpment, while Childress et al. (1986) and
Fisher et al. (1987) described a similar association at the Louisiana hydrocarbon seep sites. In both cases TEM descriptions of the bacterial morphology showed large coccoid cells with the typical Type I intracytoplasmic membrane stacks. These are different from the rod-like bacteria in Siboglinum poseidoni. Enzyme assays for methanol dehydrogenase or hexulosephosphate synthetase gave further evidence for the methylotrophic nature of the gill symbionts.

A variety of other organisms from different hydrocarbon seep sites are possible candidates for symbiosis with methylotrophs. All these animals, which include tube worms, bivalves and gastropods, are unusually depleted in ${ }^{13} \mathrm{C}$, showing $\delta^{13} \mathrm{C}$-values $<-50 \%$ but have not yet been investigated more closely (Paull et al. 1985, Kulm et al. 1986, Brooks et al. 1987). Caution is needed in attributing methanotrophy solely from carbon isotope data. The first suggestion of methanotrophic nutrition of Pogonophora (Southward et al. 
1981) was based on the great depletion of ${ }^{13} \mathrm{C}(-36$ to $-46 \%$ ) in species of Siboglinum which are now known to be dependent on sulphur-oxidizing bacteria (Southward et al. 1986).

Siboglinum poseidoni has been identified in only 2 very restricted areas in the Skagerrak (Flügel \& Langhof 1983). In these areas the pogonophores have a very patchy occurrence. Box corer samples showed that there must be small spots, not larger than a few $\mathrm{m}^{2}$, where a dense population of this species lives and the sediment is more reduced than in the surrounding areas. To elucidate this phenomenon and to learn more about the origin of the methane, an analysis of sediment gases, including hydrocarbons, was carried out. We also investigated the $S$. poseidoni symbiosis in respect of its enzymatic capabilities and carbon isotope composition to assess the extent to which methane may contribute to the tissue carbon of the pogonophore.

\section{MATERIAL AND METHODS}

Sampling. Specimens of Siboglinum poseidoni (Pogonophora), Thyasira sarsi (Bivalvia), and Leanira sp. (Sigalionidae, Polychaeta) were collected with a beam trawl and a Van Veen grab in the Skagerrak $\left(58^{\circ} 02.85^{\prime} \mathrm{N} ; 9^{\circ} 40.04^{\prime} \mathrm{E}\right)$ at 280 to $340 \mathrm{~m}$ water depth (Flügel \& Langhof 1983).

Sediment samples ( 0 to $10 \mathrm{~cm}$ depth) for gas analysis were taken from a Van Veen grab containing a dense population of Siboglinum poseidoni. Material from this grab was also used for the analysis of carbon isotopes in organic matter. Sediment from deeper layers $(60$ to $70 \mathrm{~cm}$ ) was sampled from a small gravity corer fitted with a $75 \mathrm{~mm}$ i.d. PVC-tube. The samples for the analysis of stable isotopes were stored at $-18^{\circ} \mathrm{C}$ before preparation.

Enzyme assays. For enzyme assays individual Siboglinum poseidoni were removed from their tubes immediately after collection and divided into the anterior part and the posterior part which included the girdle region. Approximately 50 individuals were used for each preparation. The combined anterior or posterior parts were gently homogenized in $200 \mu \mathrm{l}$ icecold, filtered seawater in an all glass Potter-Elvehjem homogenizer. The homogenate was centrifuged for 2 min at $6700 \times g$. The pellet which contained the bacteria was re-homogenized in $200 \mu \mathrm{l}$ distilled water to rupture the bacteria and this second homogenate was used for enzyme assays.

The protein content of the homogenates was determined by the method of Bradford (1976)

Hexulosephosphate synthetase activity was assayed on 10 to 50 ul aliquots of tissue homogenate using ${ }^{14} \mathrm{C}$ labelled formaldehyde as substrate (Levering et al. 1981). The formaldehyde concentration was $2 \mathrm{mM}$, unless otherwise stated, and the incubation time varied between 10 and $60 \mathrm{~min}$ at a temperature of $20^{\circ} \mathrm{C}$. The enzyme activity was stopped by the addition of $300 \mu \mathrm{l}$ of ethanol and $200 \mu \mathrm{l}$ of $5 \%$ barium chloride solution to the $200 \mu$ reaction mixture in $2 \mathrm{ml}$ Eppendorf microcentrifuge tubes. The tubes were stored at $4{ }^{\circ} \mathrm{C}$ overnight, centrifuged and washed 3 times with a mixture of $100 \mathrm{mM}$ formaldehyde : ethanol: $5 \%$ barium chloride solution $(1: 1: 1)$, with centrifuging after each wash. Some control tubes were stopped at zero time and other controls were incubated for the assay period in the absence of added ribose-5-phosphate. Radioactivity in the final precipitate was measured in a liquid scintillation counter after the addition of $10 \mathrm{ml}$ Instagel (Packard) scintillation fluid.

Methanol dehydrogenase (E. C. 1.1.99.8) was determined according to Anthony \& Zatman (1965) using $50 \mu \mathrm{l}$ aliquots of the homogenate.

Determination of stable carbon isotopes. Organic matter was extracted from the sediments by dichloromethane in a standard soxhlet apparatus. A possible isotope fractionation towards lighter isotopes by preferential extraction of lipids cannot be excluded but seems negligible considering the strong ${ }^{13} \mathrm{C}$-depletion in methane-influenced samples. After extraction and evaporation of the solvent the residue was heated at $850^{\circ} \mathrm{C}$ and oxidized with cupric oxide in a quartz vessel. Dried animal tissues were similarly combusted to form $\mathrm{CO}_{2}$

Free gases were removed (and then collected) from the sediments in a vacuum (water vapour pressure) while stirring the wet, unsieved samples. After sieving the sediments (washing in water) sorbed gases were released from the fraction $<63 \mu \mathrm{m}$ by adding phosphoric acid to the stirred samples in the vacuum system (Faber \& Stahl 1983, Faber et al. in press). Gas concentrations in the sediments and compositions were determined in a gas chromatograph fjtted with FID (flame ionization detector) and TCD (temperature conductivity detector). Sediment methane concentration (yield) is given as weight of methane per weight of wet sediment $\times 10^{9}(\mathrm{ppb})$. For stable carbon isotope determination the hydrocarbons were separated in a gas chromatographic column and online-combusted to $\mathrm{CO}_{2}$ (Dumke et al. 1989).

Isotope ratios were determined on the $\mathrm{CO}_{2}$ in a Finnigan MAT 250 mass spectrometer. Carbon isotope ratios are given in the $\delta$-notation with reference to the PDB standard:

$$
\begin{gathered}
\partial=\left(\left(R_{\text {sampie }} / R_{\text {standard }}\right)-1\right) \times 1000(\%) \text { where } \\
R={ }^{13} \mathrm{C} /{ }^{12} \mathrm{C} .
\end{gathered}
$$

The accuracy of the carbon isotope data is $0.2 \%$ for organic matter and better than $1 \%$ for the hydrocarbon gases. 
Table 1. Siboglinum poseidoni. Activity of hexulosephosphate synthetase and methanol dehydrogenase in tissues. Values in parenthesis are based on whole homogenate protein, i.e. including supernatant before osmotic rupture of bacteria. Preparation 4 (a): untreated; 4 (b): + toluene; 4 (c): + lysozyme. Preparation 5 was measured at a lower formaldehyde concentration (0.5 mM) than the others. nd: Not determined

\begin{tabular}{|c|c|c|c|}
\hline Preparation no. & Section of pogonophore & \multicolumn{2}{|c|}{$\left(\mu \mathrm{mol} \mathrm{g} \mathrm{g}^{-1}\right.$ protein $\left.\mathrm{min}^{-1}\right)$} \\
\hline 1 & Posterior & $103.5(8.04)$ & $45.9(3.6)$ \\
\hline 1 & Anterior & $5.1(1.0)$ & $4.1(0.8)$ \\
\hline 2 & Posterior & $286.7(28.2)$ & $20.3(2.0)$ \\
\hline 2 & Anterior & $1.3(0.24)$ & nd \\
\hline 3 & Posterior & $165.9(14.5)$ & $5.8(0.5)$ \\
\hline $4(\mathrm{a})$ & Posterior & nd & $4.3(1.3)$ \\
\hline (b) & Posterior & nd & $8.8(2.8)$ \\
\hline (c) & Posterior & nd & $10.9(3.4)$ \\
\hline 5 & Posterior & $36.2(3.6)$ & $6.2(0.6)$ \\
\hline 5 & Anterior & $0 \quad(0)$ & $1.5(0.3)$ \\
\hline
\end{tabular}

\section{RESULTS}

\section{Enzyme assays}

Table 1 lists the activities of hexulosephosphate synthetase and methanol dehydrogenase in preparations of anterior and posterior sections of Siboglinum poseidoni. Figures are given for the specific activity in the bacteria-containing pellet and also for the activity based on the total protein content of the preparation. Most of the protein was contained in the first supernatant. It is probable that not all the bacteria were lysed by a single homogenization with distilled water (Southward et al. 1986), and an attempt was made to increase the enzyme activity by adding a drop of toluene and also by preincubating the homogenate in the presence of lysozyme. These treatments increased the amount of methanol dehydrogenase activity in Preparation 4. The time-course of the hexulosephosphate synthetase assay was found to be linear over a 40 min period.

\section{Carbon isotope analysis}

Results for benthic organisms and organic matter in the sediment are given in Table 2. The tissues of Siboglinum poseidoni are extremely depleted in ${ }^{13} \mathrm{C}$. Their $\delta^{13} \mathrm{C}$-values range from $-78.3 \%$ (bacteria-containing posterior parts) to $-73.6 \%$ (bacteria-free anterior parts), while the tubes belonging to this species show a $0^{13} \mathrm{C}$ of $-62.2 \%$, probably because of contamination with heterotrophic bacteria growing on the tube.

These ratios contrast with those found in Thyasira sarsi from the same habitat. This bivalve contains sulphur-oxidizing bacteria (Dando \& Southward 1986).
The bacteria-containing gills $\left(\delta^{13} \mathrm{C}=-39.5 \%\right)$ are slightly more depleted than the rest of the body $\left(\delta^{13} \mathrm{C}=\right.$ $-37.4 \%$ ). Both values reflect the different carbon source compared to $S$. poseidoni.

Leanira sp., a polychaete feeding on organic matter in the sediment, had a ${ }^{13} \mathrm{C}$-value of $-20.0 \%$, similar to that of extracts from the organic matter of the sediment $(-25.3 \%$ to $24.5 \%$ )

The free gases (Table 3a) mainly consist of nitrogen and oxygen (air contamination), with traces of carbon dioxide and methane. Higher hydrocarbon gases were not detected. The carbon isotope data $\left(\delta^{13} \mathrm{C}=-72.9 \%\right.$ and $-80.3 \%$ ) clearly show the bacterial origin of the methane (Rice 1980) which is supported by the absence of higher hydrocarbons $\left(\mathrm{C}_{2+}\right.$-compounds were not detected, therefore the exact $\mathrm{C}_{1} / \mathrm{C}_{2}+\mathrm{C}_{3}$-ratios cannot be calculated). The isotope ratio of the associated carbon dioxide was $-19.4 \%<00{ }^{13} \mathrm{CO}_{2}<17.7 \%$. The concentration of free methane was $24 \mathrm{ppb}$ in the upper layer $(0$ to $10 \mathrm{~cm}$ ). In the 60 to $70 \mathrm{~cm}$ layer (from a separate gravity corer) a concentration of only $4 \mathrm{ppb}$ was found. This sample may not have been taken in a pogonophore zone.

Table 2. Carbon isotope data from organisms and organic matter in the sediment

\begin{tabular}{|lll|}
\hline BGR-No. & \multicolumn{1}{c|}{ Sample } & $\delta^{13} \mathrm{C}(\%)$ \\
\hline 109155 & Siboglinum poseidoni, anterior part & -73.6 \\
109156 & Siboglinum poseidoni, posterior part & -78.3 \\
109157 & Siboglinum poseidoni, tube & -62.2 \\
110486 & Thyasira sarsi, gills & -39.5 \\
110487 & Thyasira sarsi, rest of body & -37.4 \\
109283 & Leanira sp. (polychaete) & -20.0 \\
109158 & Organic matter in sediment, 0-10 cm & -25.3 \\
109281 & Organic matter in sediment, 0-10 cm & -24.5 \\
109282 & Organic matter in sediment, $60-70 \mathrm{~cm}$ & -24.6 \\
\hline
\end{tabular}


Table 3 (a). Concentrations and carbon isotope data of free gases in sediment samples

\begin{tabular}{|ccccccc|}
\hline BGR-No. & $\begin{array}{c}\text { Depth } \\
(\mathrm{cm})\end{array}$ & $\begin{array}{c}\mathrm{CO}_{2} \\
(\% \text { of total gas })\end{array}$ & $\begin{array}{c}\mathrm{CH}_{4} \\
\text { Yield- } \mathrm{CH}_{4}\end{array}$ & $\begin{array}{c}\mathrm{o}^{13} \mathrm{C}_{1} \\
(\mathrm{ppb})\end{array}$ & $\begin{array}{c}\delta^{13} \mathrm{C}-\mathrm{CO}_{2} \\
(\%)\end{array}$ \\
\hline 109281 & $0-10$ & 0.05 & 0.50 & 24 & -80.3 & -19.4 \\
109282 & $60-70$ & 4.58 & 0.34 & 4 & -72.9 & -17.7 \\
\hline
\end{tabular}

Table 3 (b). Concentrations and carbon isotope data of sorbed hydrocarbon gases in sediment samples

\begin{tabular}{|c|c|c|c|c|c|c|c|c|c|c|}
\hline BGR-No. & $\begin{array}{l}\text { Depth } \\
(\mathrm{cm})\end{array}$ & $\mathrm{CH}_{4}$ & $\begin{array}{r}\mathrm{C}_{2} \mathrm{H}_{6} \\
1 \%\end{array}$ & $\begin{array}{l}\mathrm{C}_{3} \mathrm{H}_{8} \\
\text { Aydroca }\end{array}$ & & $\mathrm{C}_{5}$ & $\begin{array}{c}\text { Yield-C } \\
(\mathrm{ppb})\end{array}$ & $\delta^{13} \mathrm{C}_{1}$ & $\begin{array}{c}\delta^{13} \mathrm{C}_{2} \\
(\%, \%)\end{array}$ & $\delta^{13} \mathrm{C}_{3}$ \\
\hline 109281 & $0-10$ & 86.7 & 7.1 & 2.8 & 1.9 & 1.5 & 100 & -40.1 & -33.5 & -32.0 \\
\hline 109282 & $60-70$ & 85.3 & 7.6 & 3.1 & 2.0 & 1.9 & 106 & -39.1 & -31.3 & -31.5 \\
\hline
\end{tabular}

The sorbed gas data are summarized in Table $3 \mathrm{~b}$. The concentration of these gases in the 0 to $10 \mathrm{~cm}$ layer was very similar to that in the 60 to $70 \mathrm{~cm}$ layer. Methane was present at a concentration of $\mathrm{ca} 100 \mathrm{ppb}$ and small amounts of higher hydrocarbons $\left(C_{2}\right.$ to $\left.C_{5}\right)$ were also found. These sorbed gases are probably of thermal origin, considering the existence of $\mathrm{C}_{2+}$-compounds $\left(\mathrm{C}_{1} / \mathrm{C}_{2}+\mathrm{C}_{3} \simeq 8\right)$ and the methane carbon isotope ratios $\left(\delta^{13} \mathrm{C}=-39 \%\right)$ which are typical for thermal gases.

\section{DISCUSSION}

Confirmation of the presence of methanotrophic bacteria in Siboglinum poseidoni is provided by the presence of hexulosephosphate synthetase and methanol dehydrogenase in extracts of the symbiont-containing post-annular tissues. Only low activities were found in the anterior sections of the pogonophores: probably because these preparations were slightly contaminated with trophosome tissue.

The activities of hexulosephosphate synthetase and methanol dehydrogenase in the bacteria-containing pellet from the post-annular tissues were comparable to those found in preparations from pure cultures of type I methanotrophic bacteria (Patel et al. 1978, Levering et al. 1981). Similar methanol dehydrogenase activities were reported from gill extracts of a mussel from a hydrocarbon seep on the Louisiana slope (Fisher et al. 1987). This mussel has endosymbiotic methanotrophic bacteria in the gills.

Activities of both enzymes in Siboglinum poseidoni were, however, lower than those reported by Cavanaugh et al. (1987) from the gills of another mussel with methanotrophic endosymbionts, from hypersaline seeps in the Gulf of Mexico. This latter mussel had enzyme activities ca 10 -fold greater than those we report in $S$ poseidoni. Since the invertebrate tissues contain eukaryote organelles in addition to bacteria, it would be expected that higher enzyme activities would be found in bacterial cultures than in the tissue extracts. It is possible that the bacteriocytes may modify the bacteria and increase the enzymes of methane oxidation to enhance the assimilation pathway.

The concentration of free methane found in sediment surrounding the pogonophores ( $24 \mathrm{ppb}$ ) was very low. In several marine sediments the concentration of bacterial methane can be higher than $300 \mathrm{ppb}$ (Faber \& Stahl 1984). Low values are often found in sediments where bacterial oxidation converts methane to carbon dioxide (Whiticar \& Faber 1986). This process generally increases the ${ }^{13} \mathrm{C}$-concentration in the remaining methane due to the ${ }^{12} \mathrm{C}$ preference of the bacteria. If the free methane is a remnant of such an oxidation then the original methane should have a more negative $\delta^{13} \mathrm{C}$ than the observed value of $-80.3 \%$. However, the process of bacterial oxidation is thought to be unlikely because the methane and carbon dioxide isotope ratios fall within the zone of bacterial methane generation/ $\mathrm{CO}_{2}$-reduction (Whiticar \& Faber 1986). The low free gas methane concentration may be explained by loss of methane during sampling or by sampling the sediment just within the zone of bacterial methane generation. In the latter case methane could have been consumed in sulphate- or oxygen-containing niches of this strongly bioturbated upper sediment layer.

Methanotrophy of the endosymbiotic bacteria of Siboglinum poseidoni is also confirmed by the carbon isotope analyses. The stable carbon isotope ratio of the bacteria-containing posterior parts of the pogonophores $(-78.3 \%)$ is very close to that of the free methane in the 0 to $10 \mathrm{~cm}$ layer $\left(0^{13} \mathrm{C}=-80.3 \%\right)$. This suggests that the free methane but not the sorbed gas is consumed by the endosymbiotic methanotrophic bacteria. The sorbed methane has a different isotopic signature (cf. Table $3 \mathrm{~b}$ ) and is believed, due to its close association with the sediment grains, to be inaccessible to bacteria or small invertebrates (Faber 1987). 
A comparison of the small difference in isotopic ratios between the anterior and post-annular parts of the pogonophores indicates that most of the carbon of the anterior parts is contributed by metabolites assimilated by the methanotrophic symbionts in the posterior. If there was no transfer of carbon from the bacteria to the pogonophore tissues and if the uptake of soluble organic comounds via the epidermis played a major role there should be a larger difference in the isotopic ratio.

The carbon isotope ratios of Siboglinum poseidoni correspond to the most negative values from organic matter known. Only a mytilid mussel with methanotrophic symbionts from the Florida escarpment site showed a comparable low $\delta^{13} \mathrm{C}_{1}-74.3 \%$ (Paull et al. 1985). Another mytilid mussel with methanotrophic symbionts from the Louisiana hydrocarbon seep sites was less depleted $\left({ }^{13} \mathrm{C}=-40.1\right.$ to $\left.-57.6 \%\right)$, indicating a dependence on thermogenic methane (Brooks et al. 1987).

Other small pogonophores from the North Atlantic which contain sulphur-oxidizing symbionts have carbon isotope ratios between -35 and $-45 \%$ (Spiro et al. 1986). These differ clearly from Siboglinum poseidoni and emphasize its special metabolic position. ${ }^{13} \mathrm{C}$ is also much less depleted in Thyasira sarsi from the Skagerrak site, $\delta^{13} \mathrm{C}=-39.5 \%$, than in the associated S. poseidoni. It is, however, interesting to note that $T$. sarsi in the Skagerrak is much more depleted in ${ }^{13} \mathrm{C}$ than T. sarsi from a fjord near Bergen (Norway) (gills: $\delta^{13} \mathrm{C}=-31.0 \%$, rest of body: $-28.2 \%$; spiro et al. 1986).

The shell carbonate in specimens of Thyasira sarsi from the Siboglinum poseidoni site has a $\delta^{1.3} \mathrm{C}$ of $-12 \%$ (B. Spiro pers. comm.)

The shell carbonate value probably represents the mixture of bicarbonate from the overlying water $\left(\delta^{13} \mathrm{C}\right.$ $\simeq 0 \%$ ) and the interstitial water from the sediment $\left(\delta^{13} \mathrm{C}=-19.4 \%\right)$. The mean temperature at $300 \mathrm{~m}$ in the Skagerrak is $6^{\circ} \mathrm{C}$ (Josefson 1986). At this temperature there is an enrichment in ${ }^{12} \mathrm{C}$ of $+3.16 \%$ in the aragonite of the shell with respect to dissolved bicarbonate (Rubinson \& Clayton 1969, Emrich et al. 1970). This implies that the bicarbonate incorporated into the shell has a mean ${ }^{13} \mathrm{C}$ of $-15.16 \%$, suggesting that the bivalve may be pumping $62 \%$ of its water from the tunnel network formed below it (Dando \& Southward 1986) and the remainder through the inhalent tube from the surface. If we assume an average $\delta^{13} \mathrm{C}$ of $-12 \%$ in bicarbonate, from the mixed water reaching the gills of the Skagerrak $T$. sarsi, and a $\Delta=-25 \%{ }^{13} \mathrm{C}$ depletion on fixation by sulphur-oxidizing bacteria (Ruby et al. 1987), then the organic carbon formed should have a $\delta{ }^{13} \mathrm{C} \simeq-40 \%$. This is very close to the observed value of $-39.5 \%$ for the entire gill (Table 2 ).
This isotope data for Thyasira sarsi from a methane seep confirms the conclusion from studies of other habitats (Dando \& Southward 1986, Spiro et al. 1986) that this bivalve obtains most of its carbon from $\mathrm{CO}_{2}$ fixed by ribulosebisphosphate carboxylase in the sulphur-oxidizing symbionts. Methanol dehydrogenase activity could not be detected in gill extracts from these $T$ sarsi. These gills were not assayed for hexulosephosphate synthetase activity but the enzyme was not detected in gill extracts from specimens obtained from the Swedish coast at Lysekil. It is therefore unlikely that the methylotrophic bacteria isolated from the gills of $T$. sarsi by Wood \& Kelly (1989) are the major symbiont species. T. sarsi is not a species usually found in the open Skagerrak, where the common species at $300 \mathrm{~m}$ are $T$. equalis, $T$. obsoleta and $T$. ferruginea (Josefson 1985). It is common in organic-rich sediments with a high sulphate-reduction rate. At the $300 \mathrm{~m}$ station it is found together with Siboglinum poseidoni, but is absent from the surrounding sediment areas. This suggests that the organic input driving the sulphate-reduction may be methane diffusing up towards the surface of the sediment. Iversen \& Jørgensen (1985) showed that at a $200 \mathrm{~m}$ depth site in the Skagerrak there was a peak in methane oxidation at $100 \mathrm{~cm}$ sediment depth which coincided with a peak in sulphate reduction. Thus methane may provide the sulphide, via sulphate reduction, needed by the symbiotic sulphur-oxidizing bacteria in $T$. sarsi as well as the carbon and energy source for the methanotrophic bacteria in S. poseidoni.

Acknowledgements. We thank Prof. H. Flügel, Prof. G. Rheinheimer and Dr E. C. Southward for critical reading of the manuscript and Mrs H. Gonschior for help in sampling the pogonophores. This work was supported by a grant from the Deutsche Forschungsgemeinschaft (Rh 8/33-2).

\section{LITERATURE CITED}

Anthony, C., Zatman, L. J. (1965). The microbial oxidation of methanol. The alcohol dehydrogenase of Pseudomonas sp. M 27 Biochem. J. 96: 808-812

Bradford, M. M. (1976). A rapid and sensitive method for the quantitation of microgram quantities of protein utilizing the principle of protein-dye binding. Analyt. Biochem. 72 : 248-254

Brooks, J. M., Kennicutt II, M. C., Fisher, C. R., Macko, S. A., Cole, K., Childress, J. J., Bidigare, R. R., Vetter, R. D. (1987). Deep-sea hydrocarbon communities: evidence for energy and nutritional carbon sources. Science 238: $1138-1142$

Cavanaugh, C. M., Levering, P. R., Maki. J. S., Mitchell, R., Lidstrom, M. E. (1987). Symbiosis of methylotrophic bacteria and deep-sea mussels. Nature, Lond. 325: 346-348

Childress, J. J., Fisher, C. R., Brooks, J. M., Kennicutt II, M. C., Bidigare, R. R., Anderson, A. E. (1986). A methanotrophic marine molluscan (Bivalvia, Mytilidae) symbiosis: mussels fueled by gas. Science 233: 1306-1308 
Dando, P. R., Southward, A. J. (1986). Chemoautotrophy in bivalve molluscs of the genus Thyasira. J. mar biol. Ass U. K. 66: 915-929

Dumke, I., Faber, E., Poggenburg, J. (1989). Determination of stable carbon and hydrogen isotopes of light hydrocarbons. Analyt. Chem. 61: 2149-2154

Emrich, K., Enhalt, D. H., Vogel, J. C. (1970). Carbon isotope fractionation during the precipitation of calcium carbonate. Earth Planet. Sci. Lett. 8: 363-371

Faber, E. (1987). Zur Isotopengeochemie gasförmiger Kohlenwasserstoffe. Erdöl Erdgas Kohle 103 (5): 210-218

Faber, E, Stahl, W. J. (1983). Analytical procedure and results of an isotope geochemical surface survey in an area of the British North Sea. In: Brooks, J. (ed.) Petroleum geochemistry and exploration of Europe. Blackwell Scientific Publications, p. 51-63

Faber, E., Stahl, W. J. (1984). Geochemical surface exploration for hydrocarbons in the North Sea. Bull. Am. Ass. Petrol. Geol. 68 (3): 363-386

Faber, E., Stahl W. J, Whiticar, M. J., Lietz, J., Brooks, J. M (in press). Thermal hydrocarbons in Gulf coast sediments In: Proc. Society of Economic Palaeontologists and Mineralogists Foundation, Gulf Coast Section: Ninth Annual Research Conference, Geochemistry of Gulf oil and gases: their characteristics, origin, distribution and exploration and petroleum significance

Fisher, C. R., Childress, J. J., Oremland, R. S., Bidigare, R. R. (1987). The importance of methane and thiosulphate in the metabolism of the bacterial symbionts of two deep-sea mussels. Mar. Biol. 96: 59-71

Flügel, H. J., Langhof, I. (1983). A new hermaphroditic pogonophore from the Skagerrak. Sarsia 68: 131-138

Iversen, N., Jorgensen, B. B. (1985). Anaerobic methane ox1dation rates at the sulfate-methane transition in marine sediments from Kattegat and Skagerrak (Denmark). Limnol. Oceanogr. 30: 944-955

Josefson, A. B. (1985). Distribution of diversity and functional groups of marine benthic infauna in the Skagerrak (eastern North Sea) - can larval availability affect diversity? Sarsia 70: 229-249

Josefson, A. B. (1986). Temporal heterogeneity in deep-water soft-sediment benthos - an attempt to reveal temporal structure. Estuar cstl. mar. Sci. 23: 147-169

Kulm, L. D., Suess, E., Moore, J. C., Carson, B., Lewis, B. T., Ritger, S. D., Kadco, D. C., Thornburg, T. M., Embley, R. W. Rugh, W. D., Massoth, G. J., Langseth, M. G., Cochrane, G. R., Scammann, R. L. (1986). Oregon subduction zone venting, fauna and carbonates. Science 2.31: 561-566

This article was presented by Professor G. Rheinheimer, Kiel, F. R. Germany
Levering, P. R., van Dijken, J. P., Veenhuis, M., Herder W. (1981). Arthrobacter P1, a fast growing versatile methylotroph with amine oxidase as a key enzyme in the metabolism of methylated amines. Arch. Mikrobiol. 129: 72-80

Patel, R. N., Hou, C. T., Felix, A. (1978). Microbial oxidation of methane and methanol: crystallization of methanol dehydrogenase and properties of holo- and apo-methanol dehydrogenase from Methylomonas methanica. J. Bacteriol. 133: 641-649

Paull, C. K., Jull, A. J. T. Toolin, L. J., Linick, I (1985). Stable isotope evidence for chemosynthesis in an abyssal seep community. Nature, Lond. 317: 709-711

Rice, D. D. (1980). Chemical and isotopic evidence of the origins of natural gases in offshore Gulf of Mexico. In: Meyers, S. D., van Wie, W. (eds.) Transactions Gulf Coast Association of Geological Societies, Vol. XXX, Society of Economic Palaeontologists and Mineralogists, New Orleans, p. 203-213

Rubinson, M., Clayton, R. N. (1969). Carbon-13 fractionation between aragonite and calcite. Geochim. cosmochim. Acta 33: 997-1002

Ruby, E. G., Jannasch, H. W., Deuser, W. G. (1987). Fractionation of stable carbon isotopes during chemoautotrophic growth of sulphur-oxidising bacteria. Appl environ. Microbiol. 53: 1940-1943

Schmaljohann, R., Flügel, H. J. (1987). Methane-oxidizing bacteria in Pogonophora. Sarsia 72: 91-98

Southward, A. J., Southward, E. C., Dando, P. R., Barrett, R. L., Ling, R. (1986). Chemoautotrophic function of bacterial symbionts in small pogonophora. J. mar. biol. Ass. U. K. 66: $415-437$

Southward, A. J., Southward, E. C., Dando, P. R., Rau, G. H., Felbeck, H., Flügel, H. (1981). Bacterial symbionts and low ${ }^{13} \mathrm{C}^{12} \mathrm{C}$ ratios in tissues of Pogonophora indicate unusual nutrition and metabolism. Nature, Lond. 293: $616-620$

Spiro, B., Greenwood, P. B., Southward, A. J., Dando, P. R. $(1986) .{ }^{13} \mathrm{C}^{12} \mathrm{C}$ ratios in marine invertebrates from reducing sediments: confirmation of nutritional importance of chemoautotrophic endosymbiotic bacteria. Mar. Ecol. Prog. Ser 28: 233-240

Whiticar, M. J., Faber, E. (1986). Methane oxidation in sediment and water column environments - isotopic evidence. Org. Geochem. 10: 759-768

Wood, A. P., Kelly, D. P. (1989). Methylotrophic and autotrophic bacteria isolated from lucinid and thyasirid bivalves containing symbiotic bacteria in their gills. J. mar. biol. Ass. U. K. 69: 165-179

Manuscript first received: October 12, 1989

Revised version accepted: December 12, 1989 